Vol. 1 No. 2 (2018)

\title{
KONFLIK PULAU IEO DENGAN CINA DAN DILEMA ALIANSI KORSEL - AS
}

\author{
Park Jaegyu \\ Hubungan Internasional, Universitas Indonesia \\ park.jaegyu@ui.ac.id
}

\begin{abstract}
This article analyzed the relationship between South Korea and the United States, an asymmetric military alliance to explain South Korea's strategy from the Ieo Iland konflit with China. Much of the previously known journals have analyzed the history, economy and security aspects of the ROK-US alliance. However, these journals couldn't have explained why South Korea built the new Naval Base on Jeju Iland. With the concept of dilemma of the alliance, this article will analyze the United States alliance policy and regime regarding North Korea's threat and China's threat. Several factors in that of the United States become the background why South Korea built the new Naval Base on Jeju Iland. The purpose of this article is to explain Cooperative Strategies, South Korea's alliance strategy which do not want to be Abandoned by the US.
\end{abstract}

Key Word :. The US-ROK Alliance, China, North Korea, Alliance Dilemma

\begin{abstract}
Abstrak
Tulisan ini menganalisa hubungan Korea Selatan dengan Amerika Serikat sebagai aliansi militer asimetris untuk menjelaskan Strategi Korsel pada konflik Pulau Ieo dengan Cina. Sebagaian besar, kajian terdahulu mengenai topik ini telah menjelaskan pentingnya keamanan Aliansi Korea Selatan dengan Amerika Serikat, historis dan politik- ekonomi. Namun, kajian-kajian tersebut belum menjelaskan mengapa Korea Selatan mengembangkan Pangkalan Angkatan Laut Pulau Jeju untuk melawan Cina. Dengan menggunakan konsep dilema aliansi, tulisan ini menjelaskan rezim, diplomasi Aliansi Amerika Serikat terhadap ancaman Korea Utara dan Cina sebagai faktor-faktor yang menjadi latar belakang pembangunan pangkalan Angkatan Laut baru di dekat daerah Pulau Ieo. Temuan tulisan ini menunjukkan bahwa diplomasi Korea Selatan tentang Aliansi tersebut merupakan Strategi Cooperate untuk tidak terjadi Penolakan oleh AS.
\end{abstract}

Kata Kunci: Aliansi Korea Selatan dengan Amerika Serikat, Cina, Korea Utara, Dilema Aliansi

I. Pendahuluan

Aliansi bisa terdiri dari berbagai jenis dengan sifat aliansi (Bruce, 1971 : 265 268). Pertama, Aliansi bisa terdiri dari aliansi masa perang dan aliansi masa damai. Aliansi masa perang terkait dengan koalisi kecuali fungsi politik. Tambahan lagi, aliansi masa perang tergantung tindakan membedakan sebagai komitmen pertahanan, komitmen kenetralan, negosiasi. Aliansi tergantung cakupan geografi terdiri dari aliansi 
seluruh dunia \& aliansi regional. Aliansi dibedakan berdasarkan sifat kepentingannya, contohnya aliansi kepentingan satu arah dan aliansi kepentingan banyak arah. Aliansi tergantung kemampuan negara, terdiri dari aliansi simetris dan aliansi asimetris. Tergantung komitmen yang ada dan tak ada, diklasifikasikan dari aliansi formal dan aliansi informal. Aliansi Korsel - AS termasuk komitmen asimetris oleh perbedaan kapabilitas militer yang besar.

Aliansi Korea Selatan (Korsel) dengan Amerika Serikat (AS) sudah terjalin lebih dari 65 tahun. Aliansi tersebut mulai dengan konflik kedua Korea. Awal mula konflik Korsel dengan Korea Utara (Korut) sendiri terjadi pada pasca kekalahan Jepang di Perang Dunia ke-2. Semenanjung Korea dibagi menjadi dua wilayah, Utara dan Selatan. Utara merupakan wilayah di bawah naungan Uni Soviet dan Selatan merupakan wilayah naungan AS. Walaupun sudah terbagi menjadi dua bagian, kedua Negara ini mengaku sebagai pemerintah yang sah atas seluruh wilayah semenanjung Korea. Saling klaim antara kedua Negara ini menyebabkan konflik bersenjata menjadi tak terhindarkan. Pada 25 Juni 1950, pasukan Korut melintasi perbatasan dan mendeklarasikan perang terhadap Korsel, Perang Korea pun dimulai. Setelah 3 tahun lamanya berperang, kedua Negara akhirnya bersepakat untuk melakukan gencatan senjata pada 27 Juli 1953 di Panmunjeon, yang akhirnya menjadi bagian dari Korut setelah sebelumnya merupakan bagian dari wilayah Korsel.

Setelah Perang itu, Aliansi Korsel AS masih tetap terjalin untuk melawan Korut. Dalam hal ini, AS dan Korsel sama-sama memperoleh keuntungan bagi keamanannya masing-masing. Keamanan Korsel meningkat dengan adanya dukungan militer AS. Sementara itu, AS mendapatkan mitra baru di Asia Timur selain Jepang.

Setelah Perang Dingin, Aliansi Korsel - AS menghadapi ancaman dari Cina yang mencoba meningkatkan kemampuan militernya hingga menjadi salah satu negara terkuat. Sejak tahun 2010, Cina menerapkan kebijakan yang lebih ofensif dalam konflik kedaulatan di Perairan Laut Cina Selatan, Laut Cina Timur, dan Laut Kuning. Cina menekankan pengembangan kekuatan Angkatan Laut dan Angkatan Udara untuk mempertahankan kepentingannya, sehingga menjadi kekuatan maritim yang dominan di kawasan. Hal ini juga didukung dengan peningkatan anggaran pertahanan nasional Cina. Peningkatan kekuatan militer Cina membuat negara negara sekitar khawatir dan membuat meningkatnya dilema keamanan di kawasan (Lee Dongryul, 2017 : 142-163). Sejak awal masa pemerintahan $\mathrm{Xi}$ Jin Ping, Cina sudah sering terlibat konflik dengan negara-negara di sekitarnya.

Cina mendemonstrasikan dan menggunakan kekuatan militernya secara sepihak sehingga menimbulkan berbagai konflik dengan negara-negara sekitarnya (Kang Byoeng Chul, 2013 : 142 - 163). Cina terlibat konflik dengan Jepang atas Pulau Senkaku. Selain itu, di Laut Cina Selatan, Cina mengalami konflik yang lebih rumit dengan Filipina, Vietnam, dan Brunei atas 'Pulau Spratly', serta potensi konflik dengan Indonesia di Perairan Natuna. Negara-negara tersebut menyikapi ancaman Cina dengan berbagai Strategi, tergantung kepentingan nasionalnya masing-masing. Filipina lebih memilih bekerja sama dengan Cina, sedangkan Indonesia saat ini mulai menunjukkan sikap tegas dengan memperkuat kekuatan maritimnya melalui pembelian kapal selam. 
Korsel juga terlibat konflik dengan Cina atas Pulau Ieo di Laut Cina Timur. Pulau Ieo berada sejauh $149 \mathrm{~km}$ dari Pulau Mara milik Korsel dan 287 km dari Pulau Diaoyu milik Cina. Pulau Ieo yang secara internasional dikenal dengan nomenklatur Socotra Rock sebenarnya bukan merupakan pulau melainkan batu karang. Jadi, konflik antara Korsel dan Cina adalah tentang Zona Ekonomi Eksklusif (ZEE) yang mengatur mengenai kepemilikan sumber daya alam di laut hingga $200 \mathrm{mil}$ dari pantai. Konfliknya juga termasuk mengenai lingkungan laut mana sajakah yang diperbolehkan sebagai tempat transit, dilewati penerbangan, dan laut lepas. Berdasarkan masalah ini, beberapa ahli keamanan menyebutkan bahwa pulau Ieo secara tidak langsung dilindungi oleh aliansi tersebut(Kim Giho, 2013).

\section{Gambar 1}

Peta Pulau Ieo

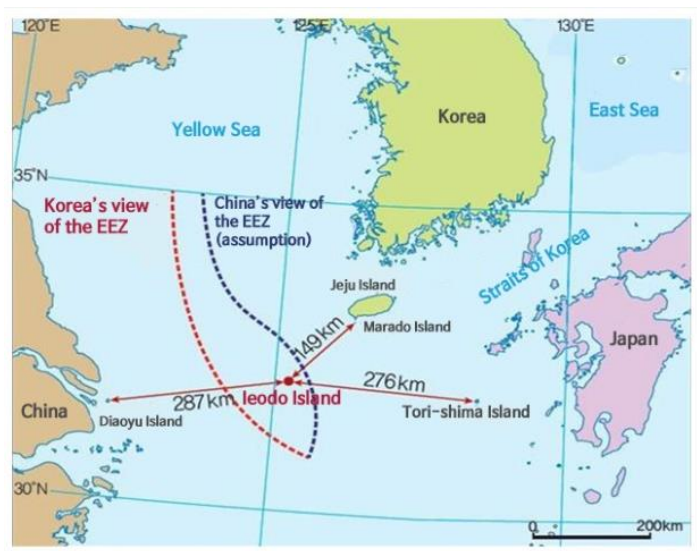

Sumber : https://www.ilovesea.or.kr

Oleh karena itu, Pemerintah Korsel mengumunkan rencana baru yang mengembangkan Pangkalan Angkatan Laut Korsel baru di dalam Pulau Jeju dan selesai membangunnya pada tahun 2016. Pada tanggl 12 Desember tahun 2015, Angkatan Laut dan Marinir membentuk Brigade ke-9 Marinir Pangkalan
Angkatan Laut Jeju (Jeju Naval Base) masing-masing sambil membubarkan Markas Besar Angkatan Laut Jeju sebelum membangun 'Pelabuhan Pariwisata dengan Menggabungkan Militer dan Sipil'(Han Chaeho, 2015). Pada tahun 2016, sudah selesai pembangunan 'Pelabuhan Pariwisata dengan Menggabungkan Militer dan Sipil'.

Tugasnya Pangkalan Angkatan Laut baru berikutnya. Pertama, Pangkalan ini bisa berfungsi seperti 'Abad Ke-21 Chunghaejin', untuk melindungi kekayaan bangsa dan keamanan. Hal tersebut bisa membantu melindungi dan mengendalikan sumber daya laut dalam laut arah selatan Pulau Jeju, dan hal tersebut membantu melindungi jalur laut sekitar Pulau Jeju sebagai sala satu jalur utama untuk memindahkan penambahan personil dan perlengkapan militer saat perang. Kedua, Pangkalan ini menjadi tempat Strategis yang sangat penting dan penghubung untuk pengelolaan kekuatan Angkatan Laut. Posisinya yang terletak di setengah Perairan Semenanjung Korea bisa memudahkan penempatan dan pergerakan kekuatan militer ke barisan depan sehingga bisa menjamin Pergerakan Kapal selam secara sembunyi. Hal itu bisa berfungsi sebagai pengawasan gerakan militer yang bisa bertugas simultan di Laut Timur, Laut Barat, dan Laut Selatan karena menggabungkan armada gerakan yang sebelumnya terpisah antara kota Busan dan kota Jinhae. Ketiga, pangkalan ini bisa menjamin perdamaian oleh Korsel

\footnotetext{
${ }^{1}$ Chunghaejin adalah pangkalan militer yang dibuat oleh jenderal Jangbogo untuk memperdagangkan barang-barang bersama jepang dan Cina pada masa raja Hengduk, tongil Silla (abada ke-9).
} 
sendiri. Ini bisa berfungsi sebagai benteng garis depan yang memiliki keunggulan secara geografis jika muncul konflik Samudra dengan negara lain. Kemudian, ini bisa berfungsi seperti pagar yang bisa melindungi kepentingan laut. Ini bisa juga melindungi aksi warga di laut seperti Lembaga Penelitian Samudra Ieo (LPSI). Keempat, pangkalan ini bisa digunakan sebagai tempat yang sangat nyaman dan pelabuhan pusat untuk pengintaian laut. Ini menyediakan fasilitas dukungan untuk pelatihan personil militer dan penyediaan alat-alat perang. Dan pangkalan tersebut bisa dijadikan sebagai tempat peristrahatan personil militer untuk mendapatkan kekuatan kembali setelah menyelesaikan misi militer dalam jangka waktu yang lama(Jeju Civilian-Military Complex Port).

Kajian terdahulu tentang Aliansi Korsel - AS umumnya mengkaji hubungan tersebut melalui tiga sudut pandang utama, yaitu (1) sudut pandang historis, (2) sudut pandang politikekonomi, (3) sudut pandang politikkeamanan. Kajian yang menggunakan sudut pandang historis umumnya mengacu pada Perang Korea tahun 19501953. Dalam hal ini, aliansi tersebut dinilai perlu untuk melindungi Korsel dari ancaman Korut serta mengamankan Semenanjung Korea (Um Taeam, 2013; Choi Gang et al, 2014). Kajian yang menggunakan sudut pandang politikekonomi berpendapat bahwa aliansi tersebut telah berkontribusi terhadap perkembangan ekonomi Korsel saat ini (Baek Jaeok, 2005). Di sisi lain, sebagian akademisi juga menilai bahwa aliansi tersebut perlu mempertimbangkan keberadaan Cina sebagai mitra perdagangan yang penting bagi Korsel (Kang Byoengchul, 2013). Sementara kajian politik-keamanan memandang aliansi tersebut dari sisi Multifaceted Strategic Alliance (Keyu Gong, 2012), Dittmer's Strategic Triangle (Mo Juneyoung, 2015), Self-Direted Diplomacy (Lee Jungnam, 2017), Limited Hedging Strategy (Lee Sanghyun, 2009; Lee Soohyung, 2015), Alliance Dilemma (Lee Jungchul, 2009; Jung Jaesung, 2016), Building Realiability (Park Youngmin 2014), dan Comprehensive Alliance (Rhee Sangwoo, 2011). Setidaknya ada tiga argumentasi utama yang muncul dalam kelompok kajian politk keamanan. Pertama, aliansi tersebut tidak membantu mewujudkan perdamaian di Semenanjung Korea. Kedua, untuk melanjutkan aliansi ini harus menyelesaikan berbagai hal. Ketiga, aliansi tersebut sangatlah penting dalam melindungi Korsel sehingga perlu dipertahankan.

Berbagai kajian di atas telah membahas faktor-faktor yang melatar belakangi pembentukan Aliansi Korsel AS serta pengaruhnya terhadap hubungan antara Korsel dengan Cina. Kendati demikian, mayoritas kajian tentang hubungan aliansi Korsel - AS dan Cina hanya terpaku pada isu penempatan THADD (Terminal High Altitude Area Defense) deployment (Hong Kyudok 2015; Jung Jinyoung 2017). Sedangkan isu-isu Strategis lainnya seperti perkembangan sengketa maritim di Pulau Ieo belum banyak dikaji. Oleh karena itu, tulisan ini akan mencoba menjawab pertanyaan mengapa dilema Aliansi Korsel - AS mempengaruhi Korea Selatan mengembangkan Pangkalan Angkatan Laut di dekat Pulau Ieo?

Untuk itu, tulisan ini menggunakan teori dilema aliansi untuk menjelaskan sikap dilema Aliansi Korsel - AS tentang konflik dengan Cina. Oleh sebab itu, tulisan ini menjelaskan operasionalisasi dari teori dilema aliansi dalam sikap 
dilema Aliansi Korsel - AS sebagai bentuk respons terhadap konflik eksternal yang dipersepsikannya, termasuk di dalamnya ialah bentuk-bentuk hubungan Aliansi Korsel - AS dan musuh (Korut, Cina) yang dianggap sebagai dilema olehnya maupun bentuk intensi dari kedua belah pihak antara Korsel dan AS. Di bagian berikutnya, secara berurutan tulisan ini menjelaskan mengenai teori dilema aliansi, pembahasan yang berisi analisa alasan Pengembangan Pangkalan Angkatan Laut Pulau Jeju dari sudut pandang teori dilema aliansi, dan bagian penutup.

\section{Metode Penelitian}

Penulis akan menggunakan teori Dilema Aliansi Penolakan (Abandonment) Keterlibatan (Entrapment) dari Glenn Herald Snyder untuk menjelaskan Strategi Korsel kepada Cina dari hubungan antara Aliansi Korsel - AS terhadap ancaman Korut dan Cina. Teori ini bisa menganalisa variabel dilema dalam aliansi tersebut untuk menjelaskan fenomena Pengembangan Pangkalan Angkatan Laut Pulau Jeju. Kemudian, untuk menunjukan dilema yang ditimbulkan oleh aliansi tersebut, tulisan ini akan menggunakan indikatorindikator penentu dalam dilema aliansi seperti Ketergantungan (Kebutuhan bantuan suatu negara, Mitra aliansi untuk mendukung suatu negara, Tingkat konflik dengan ketegangan suatu negara, dan Alternatif yang dimiliki negara untuk beraliansi ulang), Komitmen dan Kepentingan aliansi.
Menurut Glenn Herald Snyder, jika sudah berhasil aliansi antara negara dalam negara, karakter dilema keamanan aliansi berbeda dengan dilema sebelum aliansi. Yaitu, negara dalam aliansi menghadapi fase kedua dari dilema keamanan aliansi. Negara dalam aliansi bisa memilih antara Cooperate atau Defect. Cooperate dengan cara memberikan komitmen yang kuat dan dukungan terhadap mitra aliansi jika berkonflik dengan musuh. Sedangkan Defect yaitu dengan menunjukkan komitmen yang amibigu dan tidak mendukung mitra aliansi jika berkonflik dengan musuh. Di dalam dilema keamanan aliansi, kerugian berkaitan dengan Penolakan atau Keterlibatan serta mitra dalam hubungan aliansi, keuntungannya adalah menjauhi Penolakan atau Keterlibatan(Glenn, 1984 : 466 - 468).

Strategi Cooperate dan Defect bisa terkait dengan Permainan Aliansi (Alliance Game) dan Permainan Musuh (Adversary Game). Strategi Cooperate serta komitmen yang kuat dapat mengurangi Resiko Penolakan (Abandonment), tetapi besar Resiko yang dihadapi suatu negara untuk terjerat dalam konflik yang melibatkan mitra aliansinya (Entrapment) serta tingkat ketegangan dan konflik dengan musuh. Di kondisi sebaliknya, sebagai Strategi Defect, jika memberikan komitmen yang lemah dan tidak jelas dalam aliansi, maka negara dalam aliansi akan terkena Resiko ditinggalkan. Namun, mengurangi reputasi untuk menyelesaikan konflik dengan musuh. 
Tabel 1

Dilema Gabungan Keamanan Dalam Sebuah Sistem Multipolar

\begin{tabular}{|c|c|c|}
\hline Strategi & Permainan aliansi & Permainan musuh \\
\hline $\begin{array}{l}\text { Pertama } \\
\text { Aliasi : Cooperate } \\
\text { Mendukung, } \\
\text { Komitmen kekuatan } \\
\text { Musuh : Defect }\end{array}$ & $\begin{array}{l}\text { Keuntungan (good) } \\
\text { 1. Mendamaikan mitra, mengurangi } \\
\text { Resiko Penolakan } \\
\text { 2. Memperkuat reputasi untuk loyalitas } \\
\text { Kerugian (bad) } \\
\text { 1. Resiko Keterlibatan } \\
\text { 2. Megurangi penawaran kekuatan } \\
\text { dengan mitra } \\
\text { 3. Pilihan penutup penyelesaian } \\
\text { 4. Memperkuat aliansi musuh }\end{array}$ & $\begin{array}{l}\text { Keuntungan } \\
\text { 1. Mencegah atau menang, musuh } \\
\text { 2. Pertinakatan reputasi untuk selesai } \\
\text { Kerugian } \\
\text { Tingkat ketegangan dan konflik } \\
\text { dengan musuh }\end{array}$ \\
\hline $\begin{array}{l}\text { Kedua } \\
\text { Aliansi : Defect } \\
\text { Menahan mendukung, } \\
\text { Komitmen kelemahan } \\
\text { Musuh : Cooperate }\end{array}$ & $\begin{array}{l}\text { Keuntungan } \\
\text { 1. Mencegah mitra, mengurangi Resiko } \\
\text { Keterlibatan } \\
\text { 2. Menambah penawaran kekuatan } \\
\text { dengan mitra } \\
\text { 3. Menjaga pilihan penyelesaian } \\
\text { 4.memecah aliansi musuh } \\
\text { Kerugian } \\
\text { 1. Resiko penolakan } \\
\text { 2. Menurunkan reputasi untuk loyalitas }\end{array}$ & $\begin{array}{l}\text { Keuntungan } \\
\text { 1. Mencegah ketegangan dan konflik } \\
\text { dengan musuh } \\
\text { Kerugian } \\
\text { 1. mendorong musuh untuk bertahan } \\
\text { lebih kuat } \\
\text { 2. Menurunkan reputasi untuk selesai }\end{array}$ \\
\hline
\end{tabular}

Sumber : Glenn H. Snyder, The Security Dilemma in Alliance Politics

Untuk menyelesaikan dilema keamanan aliansi, suatu negara memilih satu Strategi dengan mempertimbangkan penukaran (Trade-off) dan perbandingan (Comparison) antara nilai dan Resiko Penolakan dan Keterlibatan(Glenn, 1984 : 467).

Snyder menjelaskan bahwa Strategi negara dalam dilema keamanan aliansi dipengaruhi oleh faktor-faktor penentu. Faktor yang terpenting yaitu, ketergantungan (Dependence) relatif terhadap mitra aliansinya (seberapa besar negara-negara dalam aliansi saling membutuhkan) dan persepsi mereka terhadap ketergantungan mitranya. Semakin besar atau kecilnya tingkat ketergantungan suatu negara dalam aliansi, maka keuntungan maupun Resiko Penolakan akan lebih dominan daripada keuntungan dan Resiko Keterlibatan. Ketergantungan terdiri dari empat bagian. Pertama, kebutuhan bantuan suatu negara oleh mitra aliansi dalam perang karena fungsi kapabilitas suatu negara tidak cukup dibandingkan dengan kapabilitas potensi musuh. Kedua, Kapabilitas mitra Aliansi untuk mendukung suatu negara. Ketiga, tingkat konflik dan ketegangan suatu negara dengan musuh. Keempat, negara memiliki alternatif untuk beraliansi ulang(Glenn, 1984 : 471 472).

Selain tingkat ketergantungan, faktor kedua adalah tingkat komitmen (explicitness) dalam perjanjian aliansi. 
Perjanjian yang ambigu cenderung untuk memaksimalkan ketakutan akan Penolakan. Suatu eksplisit yang meminimalkan kekhawatiran itu, yaitu dengan tidak menyingkirkan ketakutan Penolakan. Jika perjanjian tersebut ambigu, negara mungkin mencari kebutuhan untuk menetap pada aliansi dalam situasi yang membuktikan loyalitas mitra aliansi. Tetapi, faktor komitmen hanya mengubah efek dari faktor dasar ketergantungan dan kepentingan. Ketidakjelasan memungkinkan faktor-faktor tersebut bekerja sepunuhnya, namun komitmen cendurung menghambat faktor efeknya. Jadi, ketergantungan asimetris oleh aliansi akan menyebabkan aliansi lebih bergantung karena rasa takut akan Penolakan. Tetapi, ketakutan tersebut akan berkurang oleh kontrak Cooperate(Glenn, 1984 : 473).

Kemudian, yang ketiga adalah Kepentingan Aliansi. Tingkat Kepentingan Aliansi adalah konflik terhadap musuh yang berbagi dengan mitra aliansi. Hal ini mengartikan semakin negara dalam aliansi merasakan perbedaan yang besar tentang Kepentingan Aliansi, semakin besar dilema yang dihadapi dalam aliansi(Glenn, 1984 : 474).

Jika suatu negara merasakan ketergantungan yang sangat tinggi, langsung atau tidak langsung, jika mitra aliansi menganggap aliansinya kurang bergantung, jika komitmen aliansi tidak jelas, dan jika tindakan mitra aliansi barubaru ini menawarkan loyal yang mencurigakan, suatu negara akan lebih takut terhadap Penolakan daripada Keterlibatan. Strategi negara cenderung meyakinkan komitmen mitra aliansinya, mendukung mitra tentang konflik spesifik dengan musuh, dan menghindari perdamaian dengan musuh. Kondisi sebaliknya akan cenderung mendorong Strategi Defect(Glenn, 1984 : 475).

Kesimpulannya, Untuk menyelesaikan dilema keamanan aliansi, suatu negara membuktikan Strategi Cooperate dengan mitra aliansi karena suatu negara merasakan Penolakan oleh mitra aliansi. Namun, suatu negara akan menaikkan tingkat ketegangan dan konflik dengan musuh. Kemudian, Untuk menyelesaikan dilema keamanan aliansi, negara akan melakukan Strategi Defect kepada mitra aliansi karena suatu negara merasakan ketergantungan oleh mitra aliansi. Tetapi, bisa terjadi Resiko Penolakan oleh mitra aliansi.

Untuk melakukan itu, tulisan ini menggunakan data-data yang bersumber dari buku, jurnal, dan artikel dari internet. Penulis mengumpulkan data tersebut selama 9 bulan, mulai dari Februari hingga September 2018. Data tersebut dikumpulkan dengan melakukan studi pustaka, penelusuran berita, khususnya dari media daring. Setelah data tersebut berhasil dikumpulkan, penulis melakukan triangulasi agar tepat menganalisa datadata. Triangulasi tersebut dilakukan dengan cara menyeusaikan data yang telah diartikan dengan pertanyaan penelitian.

\section{Hasil dan Pembahasan}

A. Besarnya Tingkat Ketergantungan Korsel Dalam Aliansi Korsel - AS

Korsel membutuhkan bantuan oleh AS sebagai mitra aliansi dalam perang karena fungsi kapabilitas Korsel tidak mencukupi dibandingkan dengan kapabilitas Korut yatiu, tingginya ketergantungan Korsel bisa diketahui melalui perbandingan kapabilitas militer antara Korsel dan Korut. Dibandingkan kuantitatif pertama, Korut memiliki jumlah personil aktif militer Angkatan Bersenjata dan Special Forces sebanyak 
1,19 juta orang yang terdiri dari 1 juta pasukan Angkatan Darat, 60 ribu pasukan Angkatan Laut, dan 110 ribu pasukan Angkatan Udara beserta 189 ribu pasukan paramiliter. Selain itu, Korut juga memiliki 600 ribu Reserved Armed Forces dan 5,7 juta paramiliter yang akan siap angkat senjata bila diperlukan(The Military Balance 2017, 2017 : 303 - 304). Korut juga didukung oleh kira-kira 4.300 tank perang utama, 2.500 panser senjata Angkatan Darat. Dari sisi senjata Angkatan Laut, Korut memiliki 430 Kapal Perang utama, 250 Kapal Serbu Amfibi, 70 Kapal Selam. Dari segi persenjataan udara, Korut memililki 810 Pesat Tempur, 290 Helikopter Serbu. Selain itu, Korut juga memiliki artileri sejumlah 14,110 dengan menggunakan kaliber $107 \mathrm{~mm}$ hingga $300 \mathrm{~mm}$ yang tersebar diwilayah Korut(Buku Putih Militer Korea Selatan 2016, 2016 : 24).

Korsel sebagai pembanding memiliki personil aktif Angkatan Bersenjata sejumlah 630 ribu orang personil yang terdiri dari 495 ribu orang Angkatan Darat, 70 ribu Angkatan Laut (termasuk Marinir), dan 65 ribu Angkatan Udara, beserta 4,5 juta Reserved Forces berada diluar personil aktif angkatan bersenjata(The Military Balance 2017, 2017 : 306-307). Korea selatan juga didukung oleh kira-kira 2.400 Tank Perang utama, 2.700 panser senjata Angkatan Darat. Dari sisi senjata Angkatan Laut, Korsel memiliki 110 Kapal Perang utama, 10 Kapal Serbu Amfibi, 10 Kapal Selam. Dari segi persenjataan udara, Korsel memililki 410 Pesat Tempur, 630 Helikopter Serbu. Selain itu, Korsel juga memiliki Artileri sejumlah 5,900 dengan menggunakan kaliber $130 \mathrm{~mm}$ hingga $239 \mathrm{~mm}$ yang tersebar diwilayah Korea selatan(Buku Putih Militer Korea Selatan 2016, 2016 : 43).
Menurut Global Fire Power, kapabilitas militer Korsel lebih besar dari Korut. Akan tetapi, berdasarkan kualitas, Korut memiliki akses terhadap Surfaceto-Surface Missile Lauchers yang mampu membawa hulu ledak nuklir. Hingga saat ini dikonfirmasi adanya paling tidak 6 $I C B M$ jenis $\mathrm{KN}-08$, sepuluh $M R B M$ jenis Nodong, lebih dari 54 SBRM jenis KN-02 dan Scud-B/Scud-C(The Military Balance 2017, 2017 : 304 - 306). Oleh sebab itu, kemampuan kapabilitas militer Korsel tidak sebanding dengan korut. Semakin ancaman oleh musuh semakin Korsel cendurung mendekati Aliansi Korsel AS.

Kapabilitas AS untuk mendukung Korsel yaitu dengan mengurangi ketergantungan Aliansi, dengan mengurangi jumlah militer di wilayah Korsel. Sejak militer AS ditempatkan di dalam Korsel, tahun 1950-an, Sejumlah militer Korea dipengaruhi oleh 6 kali pengurangan kebijakan dan 3 kali kenaikan kebijakan. Setelah Teror 11 September, AS mengurangi sejumlah militer dengan Kebijakan Tinjauan Posisi Global (Global Posture Review). Dengan demikian, presiden AS, Bush menerapkan pengurangan kebijakan sejumlah militer AS di Korsel untuk mendukung Perang Irak. Hal ini berarti sekitar 3.600 orang militer yang hampir sama besar dengan dua Brigade meninggalkan Semenanjung Korea. Tidak kembali lagi ke Korsel setelah Perang Irak(Park Suchan, 2018). Jadi, berdasarkan Militer Balance 2017, ada sekitar 28.500 orang yang terdiri dari 19.200 orang Angkatan Darat, 250 orang Angkatan Laut, 250 orang Marinir, dan 8.800 orang Angkatan Udara(The Military Balance 2017, 2017: 44) sejak tahun 2008. Namun, jumlah tersebut masih kurang jika dibandingkan dengan jumlah militer AS di Jepang, yaitu sekitar 
2.900 orang Angkatan Darat, 12.000 orang Angkatan Laut, 20.700 orang Marinir, dan 11.450 orang Angkatan Udara, dengan total 47.050 orang(The Military Balance 2017, 2017 : 238).

AS juga meminta untuk mengembalikan Kendali Operasional Masa Perang (KOMP). Yaitu, dengan mengurangi ketergantungan Aliansi. Pada awal perang semenanjung Korea, tahun 1950, presiden Korsel meminta KOMP militer Korea kepada Panglima PBB untuk operasi perang secara efektif. Selanjutnya, pada tahun 1978, Komandan Pasukan Gabungan Korea Selatan dan Amerika Serikat (ROK-US Combined Forces Command) dibangun. Dalam perjanjian kerja sama militer antara Korsel dan AS, AS akan mengendalikan Operasional Pasukan Korsel di masa depan. Karena Perang Korea diakhir pada 1953 sebuah perjanjian genjatan senjata bukan perdamaian. Oleh karena itu, AS mempunyai KOMP di bidang militer korsel. Akan tetapi, menurut AS, militer Korsel semakin hari sudah semakin maju dan semakin mampu untuk mengendalikan Operasi Tempur(Ervan Hardoko, 2013). Jadi, AS menuntut masalah ini dalam jangka waktu yang lama, hal tersebut terjadi sejak awal tahun 1988. Setelah tahun 2000, kedua negara dalam aliansi menyetujui kebutuhan diskusi secara komprehensif melewati persepsi atas keamanan di Asia Timur berubah. Mereka membuat melaksanakan Pertemuan Inisiatif Kebijakan Aliansi Korea Selatan - Amerika Serikat (Future ROK-US Alliance Policy Initiatives) pada tahun 2003 dan memperluas fungsi pertemuan tersebut dengan berganti sebagai inisiatif kebijakan keamanan pada tahun 2005. Dalam Pertemuan Penasihat Keamanan (Security Sonsultative Meeting) Korsel-AS ke-37, kedua menteri pertahanan membicarakan perundingan terhadap waktu KOMP. Mereka menyepakati penyelidikan bersama melaui PPK tentang visi aliansi tersebut. Pada tahun 2006, kedua negara menyetujui kembali KOMP dalam KTT Korsel -AS. Bukan hanya itu, di dalam PPK ke-38 menyepakati rencana terhadap sistem militer aliansi baru setelah kembali KOMP yang akan kembali dari tahun 2009 tanggal 15 oktober sampai tahun 2012 tanggal 15 maret yang terlambat(Choi Sengjin, 2006). Namun, pada tanggal 26 Juni tahun 2010, Kedua negara kembali menyetujui menunda waktu KOMP karena pengelolaan stabilitas terhadap situasi keamanan di Semenanjung Korea, jaminan damai setelah kembali KOMP, dan isu rudal Korut tenggelamkan kapal militer Korsel pada tahun 2010. Akan tetapi, pada tahun 2014, di dalam PPK-46 kembali menunda masalah KOMP secara tidak terbatas serta menyepakati KOMP yang berdasarkan beberapa syarat oleh ancaman external seperti rudal dan persenjatan nuklir dari Korut.

Tingkat konflik dan ketegangan Korsel dengan Korut. Menurut teori Snyder, semakin besar tingkat konflik dan ketegangan Korsel dengan Korut, semakin besar pula ketakutan Penolakan dari AS. Korsel dan korut bukan untuk mengakhiri perang melainkan untuk gencatan senjata (perang) sejak tahun 1953. Oleh sebab itu, Semenanjung Korea selalu mempunyai ketegangan yang tinggi. Untuk mencegah benturan kekuatan militer, kedua negara juga sepakat atas pembentukan sebuah wilayah perbatasan yang berfungsi sebagai zona penyangga (buffer zone). Wilayah tersebut dikenal sebagai Zona Demiliterisasi (ZD) atau Demilitarized Zone (DMZ) sepanjang 155mil. Angkatan Darat Korsel mengawasi wilayah tersebut selama 24 jam setiap harinya, karena 
adanya ancaman dari Korut. Semakin besar ancaman dari Korut semakin besar pula ketegangannya. Contohnya, Peristiwa yang sangat penting terjadi pada 4 Agustus 2015, yaitu peristiwa saat dua buah ranjau darat meledak di dalam ZD yang membentuk penyangga Korsel. Saat peristiwa ini, dua orang perwira militer Korsel menjadi korban(Lee Simchul, 2015). Korsel menuntut Korut sebagai dalang penyebab terjadinya peristiwa ini. Di Laut Kuning juga membuat garis untuk mencegah benturan kekuatan militer yang dikenal sebagai Garis Batas Utara (GBU) atau Northern Limit Line (NLL). Akan tetapi, Korut menuntut tidak menyetujui GBUnya sejak tahun 1973. Korut terus-menerus mengancam Korsel di wilayah perbatasan tersebut, hal tersebut tidak mengurangi konflik dan ketegangan di Semenanjung Korea.

AS memiliki alternatif untuk beraliansi ulang. Suatu negara yang mempunyai alternatif bisa mengurangi ketakutan Penolakan dan Keterlibatan. Sebaliknya, negara yang tidak ada alternatif merasakan ketakutan Penolakan dan Keterlibatan. AS menggunakan alternatif antara Aliansi Korsel - AS dan Aliansi Jepang - AS. Yaitu, AS sudah memperkuat Aliansi Jepang - AS pada tahun 2015. Pada waktu bualn April tahun 2015, Presiden Jepang mengunjungi AS untuk Konferennsi Tingkat Tinggi AS dan Jepang. Kedua negara menandatangani garis panduan baru terhadap Aliansi Jepang - AS. AS memeperluas ruang peran Jepang tentang keamanan Kawan Asia - Pasifik. Tujuan ini menyesuaikan diri dengan ancaman Cina, Russia, Korut. Jepang dan US memperbaiki Defense Cooperationnya untuk memperluas kekutatan Badan Pertahanan Nasional (BPN) dan menjadi globalisai terhadap Aliansi Jepang AS.
Sebagai garis panduan baru terhadap Aliansi Jepang - AS berikunya;

Pertama, kesinambungan kerja sama antara Jepang dan AS. Yang kedua, Badan Kerja Sama yang mengendalikan operasi antara kedua negara, yaitu, control mechanism dibangun di masa damai. Yang ketiga, BPN Jepang menawarkan pengamanan waktu militer AS melakukan patroli untuk pertahnan Jepang. Yang keempat, Jepang memperluas daerah untuk mendukung AS jika militer AS berkonflik terkait dengan keamanan Jepang. Yang kelima, Alians Jepang - AS mendukung untuk pertahanan kepulauan Jepang. Yang keenam, BPN Jepang bekerja sama Operasi Laut seperiti penghapusan ranjau di Jalan Laut. Yang ketuju, penguatan kerja sama globalisasi seperti Kegiatan Pemeliharaan Perdamian. Yang kedelapan, penguatan kerja sama bidang dunia maya dan ruang angkasa. Oleh karena itu, Jika AS berkonflik dengan Korut, Jepang lebih cepat mendukung AS. AS mengurangi ketergantungan Aliansi Korsel - AS untuk melawan Korut.

Menurut teori Sydner, untuk Korsel menyelesaikan konflik dengn Cina tentang Pulau Ieo, bisa memilih Dua Strategi. Pertama adalah Korsel bekerja sama dengan Aliansi AS untuk melawan Cina. Yang kedua adalah Korsel Defect Aliansi AS untuk mencegah ketegangan dan konflik dengan Cina. Dari analisis tersebut, Korsel merasakan Resiko Penolakan tentang ancaman Korut dari AS. Korsel memilih Strategi Cooperate dengan Aliansi AS. Karena semakin besar tingkat ketergantungan Korsel dalam Aliansi Korsel - AS, maka keuntungan maupun Resiko Penolakan akan lebih dominan daripada keuntungan dan Resiko Keterlibatan. Oleh karena itu, Korsel harus menunjukkan Strategi 
Cooperate kepada Aliansi Korsel - AS. Korsel sudah mengembangkan Pangkalan Angkatan Laut di dekat Pulau Ieo pada tahun 2016 untuk melindungi Pulau Ieo terhadap ancaman Cina.

\section{B. Tingkat Komitmen Dalam Perjanjian Aliansi Korsel - AS}

Menurut teori Snyder, perjanjian yang ambigu cenderung untuk memaksimalkan ketakutan akan penolakan. Perjanjian Pertahnan Bersama Antara Amerikat serikat dan Korea Selatan (Mutual Defense Treaty Between the United States and the Republic of Korea) tidak dijelaskan tentang Intervensi Perang Secara Otomatis. AS tidak wajib mendukung militer walaupun Korut mengancam atau menyerang Korsel dengan kekuatan militer. Korsel harus menjelaskan hal itu sendiri atau meminta bantuan militer oleh AS. Berikut adalah Perjanjian Pertahnan Bersama Antara Amerikat Serikat dan Korea Selatan(Yale Law School Lillian Goldman Law Library);

\section{Pasal I}

Kedua negara menyelesaikan sengketa internasional di mana mereka mungkin terlibat secara damai sedemikian rupa bahwa perdamaian, keamanan dan internasional keadilan tidak terancam. Dan untuk mempertahankan diri dalam hubungan intrnasional dari ancaman atau penggunaan kekerasan dengan cara apapun tidak konsisten dengan tujuan Amerika serikat, atau kewajiban diasumsikan oleh pihak terhadap Amerika serikat.

Pasal II

Kedua negara akan bersama-sama berkonsultasi dan saling berpendapat satu sama lain jika kemerdekaan politik atau keamanan negara masing-masing terancam oleh serangan bersenjata dari luar. Mereka saling membantu, kedua negara akan mempertahankan dan mengembangkan sarana untuk mencegah serangan bersenjata yang tepat dan akan mengambil langkah-langkah yang cocok di konsultasi dan persetujuan untuk melaksanakan Perjanjian ini dan untuk memajukan tujuan.

Pasal III

Setiap negara mengakui bahwa serangan bersenjata di daerah pasifik pada salah satu pihak dalam masing-masing wilayah, sekarang di bawah kontrol administratif diakui oleh salah satu pihak secara sah di bawah kontrol administratif yang lain, akan berbahaya jika negara berdiri sendiri dalam kesejahteraan atau keamanan dan menyatakan bahwa akan bertindak untuk memenuhi bahaya umum sesuai proses konstitusional.

Pasal IV

Korea Selatan menyutujui dan Amerika Serikat menerima hak untuk menempatkan Angkatan Darat, Angkatan Laut dan Angkatan Udara Amerika Serikat di sekitar wilayah korea selatan ditentukan sebagai kesepakatan bersama.

Pasal V

Perjanjian ini harus diratifikasi oleh Amerika Serikat dan Korea Selatan sesuai dengan proses konstitusional masing-masing negara, dan akan mulai berlaku ketika instrumen ratifikasinya telah ditukar oleh mereka di Washington.

Pasal VI

Perjanjian ini akan tetap berlaku tanpa batas waktu. Setiap negara dapat mengakhirinya satu tahun setelah pemberitahuan yang telah diberikan kepada negara lain. 
Berdasarkan teori Snyder, Ambigu tentang Intervensi Perang Korea Secara Otomatis dalam Perjanjian tersebut cenderung untuk memaksimalkan ketakutan seperti Penolakan tentang ancaman Cina. Korsel harus bisa melindungi Pulau Ieo sendiri. Jadi, Korsel sudah mengembangkan Pangkalan Angkatan Laut di Pulau Jeju untuk melindungi Pulau Ieo terhadap ancaman Cina.

\section{Perbedaan Kepentingan Aliansi Antara Korsel Dan AS}

Menurut teori Snyder, Perbedaan Kepentingan Aliansi antara Korsel dan AS mengartikan semakin antara Korsel dan AS merasakan perbedaan yang besar tentang Kepentingan Aliansi, semakin Korsel merasakan besar ketakutan Penolakan yang dihadapi dalam Aliansi Korsel - AS. AS mencari Kepentingan Alisnsi antara mitra aliansi untuk melawan ancaman Cina yang mencoba memperluas wilayah kekuatan.

Cina memperluas wilayah kekuatan atas laut untuk menjadi Negara Hegemoni. Angkatan Laut Cina mencoba menerobos Rantai Pulau Kedua (second iland chain) untuk melindungi kepentingan negara Cina di luar Rantai Pulau Pertama (first iland chain). Mereka menuntut persiapan konflik dengan Taiwan, perlindungan kedaulatan perairan dan perlindungan jalan perairan. Rantai Pulau Pertama adalah garis imajiner yang terkait dengan Korsel, Jepang, Okinawa, Taiwan, Phlipina, dan Perairan Utara Indonesia. Rantai Pulau Kedua adalah garis imajiner yang terkait dengan setengah dari Jepang, Pulau Ogasawara, Pulau Mariana, dan Selandia Baru(Kang Byoeng Chul, 2013 : 153 154). Sedangkan, "Strategi balancing yang dilakukan oleh AS melalui penguatan aliansi militer merupakan
Strategi yang sesuai untuk mempersempit ruang gerak Cina untuk mendominasi Kawasan Asia-Pasifik"(Vanilla Planifolia, 2017).

Menurut Snyder, Korsel merasakan ketakutan penolakan oleh AS jika tidak menyetujui kebijakan AS untuk mengurangi perbedaan Kepentingan Aliansi. Jadi, Korsel harus bisa melindungi Pulau Ieo sendiri. Yaitu, Korsel sudah selesai mengembangkan Pangkalan Angkatan Laut di Pulau Jeju untuk menjelaskan masalah Pulau Ieo. Awalnya, Cina tidak memperbesar masalah Pulau Ieo karena pengaruh aliansi Korsel - AS. Tetapi, ada banyak sumber daya alam di sekitar wilayah perairan Pulau Ieo, yang membuat Cina memulai konflik tersebut.

\section{Kesimpulan}

Aliansi Korsel dengan AS sudah terjalin lebih dari 65 tahun. Sejak itu, sikap aliansi tersebut berganti dengan ancaman eksternal dalam perubahan politik seluruh dunia dan perbedaan kepentingan antara kedua negara. Setelah perang dingin, kemunculan Hegemoni Cina mempengaruhi Aliansi tersebut. Ada pemimpin Cina yang menjadi kekuatan maritim yang dominan di kawasan. Oleh karena itu, Strategi Cina bersaing dengan Strategi Rebalancing AS di bidang keamanan. Antara hegemoni AS dan Cina, korsel bisa memilih 3 poin dsasar yang bisa mempertahankan kehidupan. Pertama, setelah mengakhiri aliansi Korsel - AS, Korsel bekerja sama dengan Cina yang ingin memimpin seluruh dunia seperti Strategi Bandwagoning. Kedua, dengan aliansi Korsel - AS melawan ancaman Cina seperti Strategi Balancing. Ketiga, Korsel bekerja sama dengan Cina untuk mengontrol ancaman melaui aliansi korsel - AS seperti Strategi Hedging. 
Sikap aliansi Korsel - AS juga berubah dalam waktu yang lama, berserta masing-masing negara menggantikan Strateginya untuk menghindari Penolakan dan Keterlibatan oleh mitra aliansinya. Korsel didukung oleh aliansi asimetris dengan AS karena sekitar wilayah Korsel selalu melindungi ancaman dan konflik yang besar beserta negara tetangga seperti Cina dan Korut yang dekat secara geografis. Korsel terus-menerus memperkuat kebijakan untuk menghindari Penolakan dan Keterlibatan untuk kepentingan negara. Sebaliknya, AS juga selalu mengubah untuk menghindari Keterlibatan dari ancaman Korsel.

Menurut Snyder, negara dalam aliansi dapat memilih untuk Cooperate atau Defect. Negara memilih satu Strategi dengan mempertimbangkan penukaran dan perbandingan antara nilai dan Resiko Penolakan atau Keterlibatan. Yaitu, Strategi negara terhadap aliansi dipengaruhi faktor - faktor penentu seperti Ketergantungan, Komitmen, Kepentingan Aliansi. Jika kondisi dalam aliansi asismetri, negara lemah lebih takut terhadap Penolakan dari negara kuat. Sebaliknya, dalam sudut pandang negara kuat, hal itu untuk menghindari Keterlibatan dengan masalah konflik

\section{DAFTAR PUSTAKA}

Baek Jaeok(2005). Arah Kebijakn Ekonomik Aliansi Korsel - As. Seoul: KIDA

Bruce M. Russett(1971). An Empirical Typology Of International Military Alliances. Midwest Jounal Of Political Science, Vol. 15(2), Hal 265 -268

Buku Putih Perairan Korea Selatan 2016. Seoul: Polisi Perairan negara yang lemah. Negara lemah mengikuti Strategi Cooperate untuk terus-menurs mempertahankan aliansi.

Berdasarkan teori ini, bisa menjelaskan masalah Korsel dengan Cina tentang Pulau Ieo. Jadi, Korsel sudah mempertimbangkan Strategi Cooperate atau Strategi Defect tentang masalah tersebut. Jika Korsel bekerja sama dengan AS untuk melawan Cina, tidak bisa menyelesai masalah Pulau Ieo dengan cara yang damai. Jika Korsel Defect AS untuk mengurangi ancaman Cina tentang masalah tersebut, Aliansi Korsel - AS menjadi lemah. Korsel tidak bisa menjamin keamanan terhadap ancaman Korut. Jadi, keuntungan Aliansi Korut AS lebih dominan daripada kepentingan antara Korsel dengan Cina karena Korsel merasakan Penolakan kepada AS tentang ancaman Korut. Untuk masalah Pulau Ieo, Korsel harus melindungi wilayah sendiri dengan kekuatan militer bersamaan membuktikan mendukung Aliansi Korsel - AS. Hal tersebut yang menjadi alasan korsel mengembangkan Pangkalan Angkatan Laut dekat Pulau Ieo.

Buku Putih Militer Korea Selatan 2016. Seoul: Menteri Pertahanan Korea Selatan

Choi Kang, Kim Jiyun, Kang Chunggu (2016). U.S.A And South Korea Alliance, Challenge And Task. Seoul: Asan Report.

Choi Sengjin(2006), SCM-38 Pernyataan Bersama, Nocut News, Diakses dari http://www.nocutnews.co.kr/news/ 204473 
Ervan Hardoko(2013), AS Dan Korsel Bahas Penyerahan Kendali Militer, Kompas, Diakses Dari https://olahraga.kompas.com/read /2013/09/30/1324252/www.bbc.co .$u k$

Glenn H. Snyder(1984). The Security Dilemma In Alliance Politics, World Politics, Vol. 36(4), Hal. $461-495$

Go Seongsik(2017), Kapal Dinas Cina Melintasi Perairan Pulau Ieo, Yonhap News, Diakses Dari https://www.yna.co.kr/view/AKR2 0170110086000056

Han Chaeho(2015), The Marine Corps Worte New History, Defense Media Agency, Diakses Dari http://demaclub.tistory.com/2877

Jeju Civilian-Military Complex Port, Diakses Dari Http://Jejunbase.Navy.Mil.Kr/

Jung Jaesung(2016). Alliance Dilemma Of The ROK-US Alliance And South Korea's Future Strategy For The Alliance, National Security And Strategy Vol.16(2)

Kang Byoeng Chul(2013). Ieodo Issue And The Evolution Of People's Liberation Army Navy Strategy, Strategy 21 Vol16(1), Hal 142163

Kim Chulhwan(2017). Sistem Pertahanan Tiga Sumbu Korsel Terhadap Ancaman Korut, Seoul: Militer Defense News

Kim Giho(2013). Aliansi Korea Selatan Dengn Amerika Serikat Adalah Kunci Jawabnya, Seoul: Defense News, Diakses

Keyu Gong(2012). The Korea-US Alliance From A Chinese Perspective, Asian Perspective, Vol.36(2), Hal. 309-330.

Ko Gyungmin(2016). Stereotyping Ieodo Disputes And
Countermeasures, National Security And Strategy Vol.16(3), Hal. 83 - 118

Kristin Huang(2017), Chinese Navy Keeps Firm Focus On Northern Shores As North Korean Tensions Rise, South China Morning Post, Diakses Dari https://www.scmp.com/news/china/ diplomacy-

defence/article/2110233/chinesenavy-keeps-firm-focus-northernshores-north

Lee Dongryul(2017). Ieodo Issue And The Evolution Of People's Liberation Army Navy Strategy, Strategy 21 Vol 16, No 1 Hal 142163

Lee Hyuno(2017), Pengupayaan Dan Analisis Kesimpulan SCM Ke-49, Konas, Diakses Dari http://konas.net/article/article.asp ?idx $=50086$

Lee Jungchul(2009). DPRK-US Confrontation And ROK-US Alliance In Transition. Korea Politic Study Vol. 18(1), Hal. 147 $-168$

Lee Jungnam(2017). South Korea's Perception And Policy On China In The Age Of Competition Between The US And China Focusing On The Approaches Of China Experts In Korea, Asian Studies Vol. 60(2), Hal. 79 - 112

Lee Sangyhun(2009). The Rise Of China And The Future Of ROKU.S. Strategic Alliance, Streategy 21, Vol. 22 Hal. 252 - 279

Lee Simchul(2015), Ranjau Darat Meledak Di Pintu Besi Yang Terkait Dengan DMZ, Tvchosun News, Diakses dari http://news.tvchosun.com/site/dat a/html_dir/2015/08/11/201508119 0005.html 
Lee Soohyung(2015). U.S. Rebalancing Strategy And ROK-U.S. Alliance: From The Perspective Of Neorealist Theory Of Hegemonic Retrenchment, Korea And International Politics, Vol. 31(2), Hal. 1 - 27

Marine Education Portal, Marine territory, Diakses Dari https://www.ilovesea.or.kr/eng/res our/territory6.do

Mo Juneyoung(2015). The Research On The Change Of Diplomatic Relations In Strategic Triangle, Ethic Studies, Vol 62, Hal. 153 178

Na Youngju(2015). China's Perception And Strategy About The Unification In The Korean Peninsula, International Relations, Vol.18(2), Hal. 109128

Park Suchan(2018), Pengurangan Militer AS Secara Bertahap Setelah Gencatan Senjata.......Saat Ini 28.500 Orang Dalam 1 Divisi, Saegae Ibo, Diakses Dari http://www.segye.com/newsView/ 20180504005395

Park Youngmin(2014). Conritions And Tasks To Establish A Peace System In Th Korean Peninsula : Focused On Relevance With Korea-U.S. Alliance, Korea Northeast Asia A Collection Of Treatises, Vol. 70, Hal. 113 -131

Rhee Sangwoo(2011). Now The Time To Bolster Alliances New Asia Reaserch Institute, Vol. 18(2), Hal. 7 -13
The Military Balance 2017, The International Institute For Strategic Studies (IISS)

Um Taeam(2013). Sixty Years Of The ROK-U.S. Military Alliance : Achievements And Future Development, Defense Policy Studies, Vol.29(2). Hal. 49 - 87

Vanilla Planifolia(2017). Strategi Rebalancing Amerika Serikat di Kawasan Asia-Pasifik, Jurnal Hubungan Internasional, Vol. 6(1)

Yale Law School Lillian Goldman Law Library, Mutual Defense Treaty Between the United States and the Republic of Korea; October 1, 1953, Diakses Dari http://avalon.law.yale.edu/20th_c entury/kor001.asp

Yun Sangho(2018), Song Kementerian Pertahanan, Kembali KMMP Sampai Tahun 2023, Donga News, Diakses Dari http://news.donga.com/home/3/all /20180511/90040760/1

\section{Biodata Penulis}

Park jaegyu, lahir di seoul 9 Des 1983, pendidikan dari SD sampai SMA di selesaikan ditempat kelahirnnya, lalu meneruskan kuliah S1 di sastra indonesia Hankuk University of Foreign Studies Seoul Korea Selatan dan sekarang belajar S2 di program pascasarjana ilmu sosial dan politik UI. Bidang keahliah keamanan internasional dan konflik maritim tentang wilayah korea selatan. 